\title{
A PRELIMINARY STUDY OF FAUNAL DIVERSITY IN MADIWALA LAKE
}

\author{
*A. Syama **P.U.Antony
}

\section{INTRODUCTION}

The need to maintain and enhance the urban and suburban populations of wild life has greatly increased in recent past due to a desire to observe wild life closer to home and a concern to protect the habitat from rapid urbanization (Shomn et al ; 1974; Hoover 1976). There is an urgent need to foster wild life awareness among urban dwellers so that policies made for wild life and protection issues can be better evaluated.

Planners who take environmental decision on limited information available on biological components of the area to be impacted also become misleading. Therefore I strongly feel that habitat requirements of individual species must be known before the implementation of management or planning schemes. Many studies have discussed the necessity for information about the habitat components that are important in the urban areas. Geis 1980 stated there is a need ..." for more research on wild life in areas to obtain detailed knowledge on the characteristics of urban fish and wild life population ". His statement emphasizes the need for publications dealing with urban wild life and their habitat management potentials. Planning for wild life in urban areas is often stiffled by inadequate support and

* Graduate Student, Christ College, Bangalore - 560029

** Senior lecturer, Dept. of Zoology, Christ College, Bangalore - 560029 
collaboration from resource agencies and lake of awareness and expertise in wild life matters by urban planners. City planners have ultimate responsibilities for incorporating wild life issues in to the planning process. But the results are not encouraging.

The solution to this dilemma is either to encourage greater collaboration between wild life regulatory agencies municipal planners or to familiarize the planners with wild life resources through literature relevant to both the disciplines. This study is a humble attempt to identify life forms in a city lake and to learn and recommend about the habitat requirements of the animals.

The major water bodies of India are facing serious threats of aquatic pollution consequent to urbanization and industrial growth. Domestic, agricultural and industrial wastes are being indiscriminately discharged into aquatic ecosystems. At present environmental studies seem to be focused more on water quality parameters than on the total ecological changes brought about in the aquatic systems. It was therefore thought it would be intresting to make a preliminary survey of the pattern and impact of various industrial and other effluents in to the lake under study.

\section{STUDY AREA}

Madiwala Lake is a fresh water lake extending to about 114.16 hectares in the B.T.M loyout on the right side of the Bangalore - Hosur highway about $8 \mathrm{kms}$ from M.G.road, the heart of the city. The total water-spread area of the lake is 750803 sqm and the total wetland area is 24.74 acres. The water holding capacity of the lake is 2236737 cubic meters.

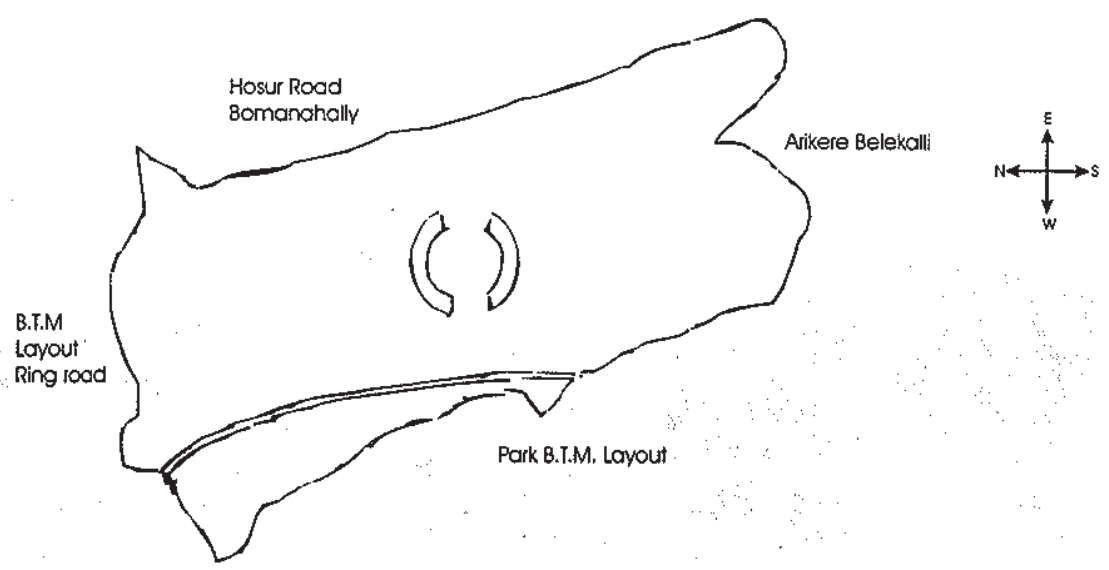




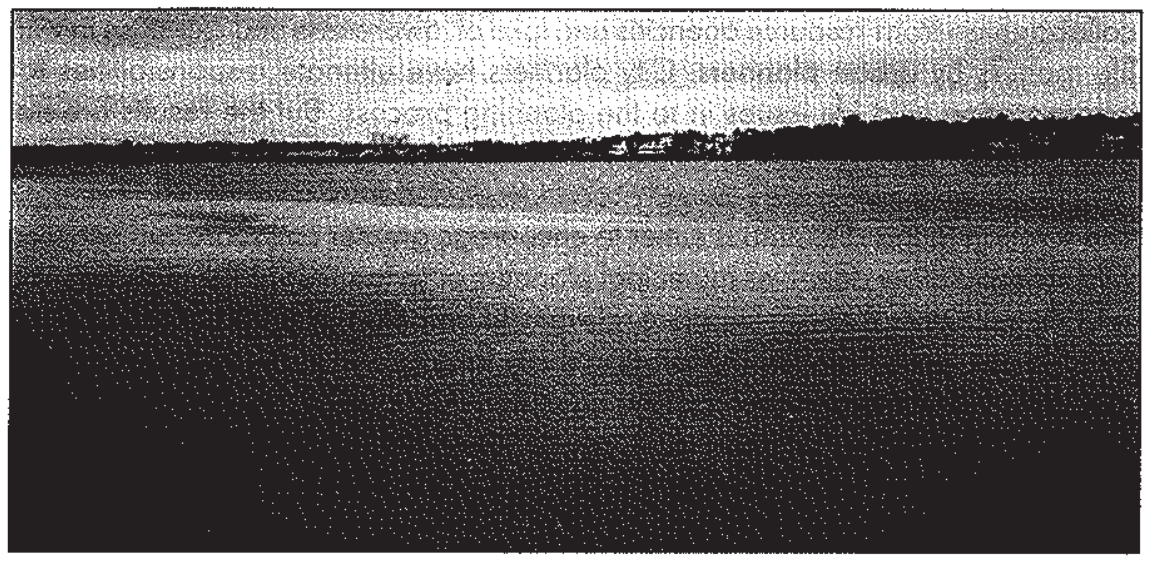

The lake is surrounded by residential areas and there is a small island in the center with moderate vegetation of bushes and under growth of tall grass and even ornamental plants. The lake is almost fully covered by Eichornia except for a span of about 30 to 40 hectares towards the north -eastern side where the Bangalore City Corporation has cleared the weeds under the Indonorweigian environment program. Towards the northeast corner of lake washer men are engaged in their business.

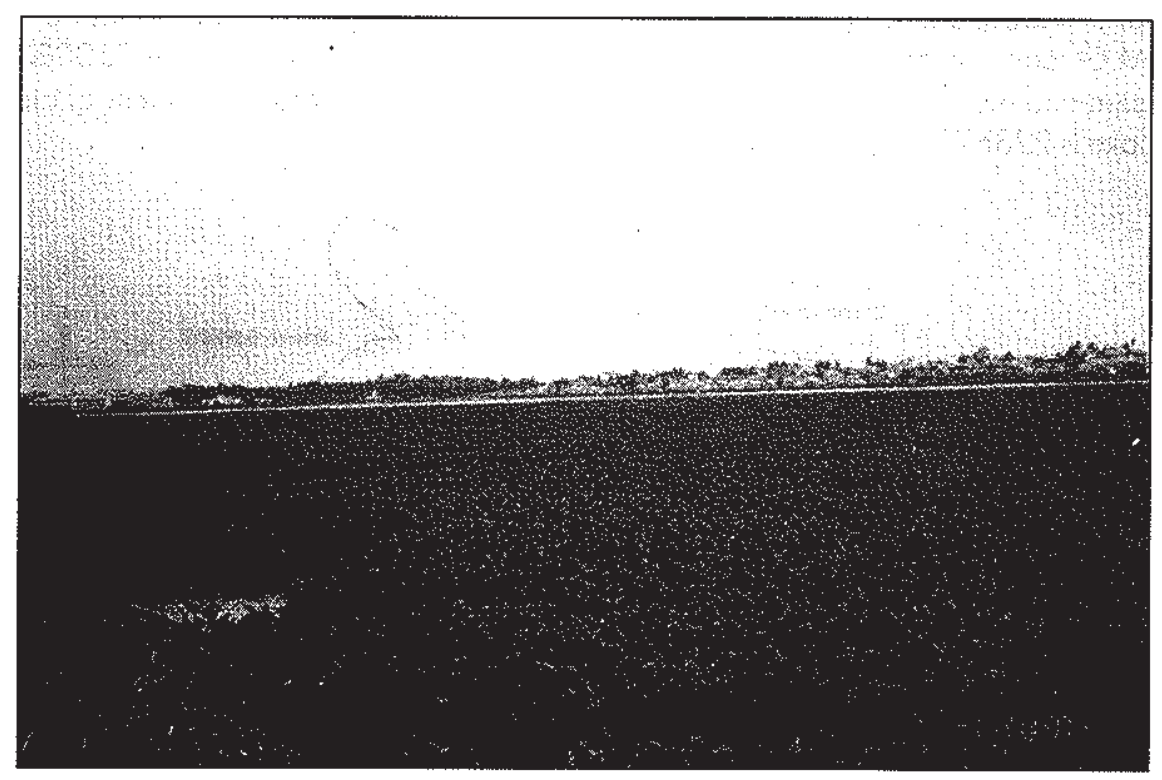




\section{METHODOLOGY}

The study area was visited four times during the month of October. Location, boundaries and zoogeography of the area were noted down. Household sewage, plastic bags, paper, detergents etc thrown into the tank. Defecation by slum dwellers. Physical examination of the water sample was done for clarity, weed growth etc. Life forms in the area was observed and noted down through naked eyes and also with the aid of an $8 \times 40$ Zenith prismatic binocular.

\section{RESULTS}

\begin{tabular}{|c|c|c|}
\hline $\begin{array}{l}\text { Turbidity } \\
\text { PH } \\
\text { Weeds } \\
\text { Organisms } \\
\text { Annelidworms } \\
\text { (soil organisms) } \\
\text { Molluscans } \\
\text { Insects } \\
\text { Fishes } \\
\text { Amphibians } \\
\text { Reptiles } \\
\text { Birds }\end{array}$ & $\begin{array}{l}\text { Tubifex } \\
9.02 \\
\text { Almost fully covered } \\
\text { Common names } \\
\text { Tubifex } \\
\text { Helix (land snail) } \\
\text { Butterflies,Mosquito larva } \\
\text { Jelabi, Chillu (local names) } \\
\text { Frog } \\
\text { Water snakes } \\
\text { 1. Indian Moor hen } \\
\text { 2. White breasted Kingfisher } \\
\text { 3. Cattle Egret } \\
\text { 4. Pond Heron } \\
\text { 5. Little Egret } \\
\text { 6. Jungle Myna } \\
\text { 7. House Crow } \\
\text { 8. Pied Bush Chat } \\
\text { 9. Little Cormorant } \\
\text { 10. Darter } \\
\text { 11. Blyth's Reed Warbler }\end{array}$ & $\begin{array}{l}\text { Nafrix natrix } \\
\text { 1. Gallinula chloropus } \\
\text { 2. Halcyon smyrnensis } \\
\text { 3. Bubulcus ibis } \\
\text { 4. Ardeola grayii } \\
\text { 5. Egreta garzetta } \\
\text { 6. Acridotheres fuscus } \\
\text { 7. Corrus splendens } \\
\text { 8. Saxicola caprata } \\
\text { 9. Phalacrocorax niger } \\
\text { 10. Anhinga rufa } \\
\text { 11. Acrocephalus dunetorum }\end{array}$ \\
\hline
\end{tabular}




\begin{tabular}{|ll|}
\hline 12. Large Pied Wag-tail & 12. Motacilla maderaspatensis \\
13. Pied Kingfisher & 13. Ceryle rudis \\
14. Brahmny Kite & 14. Haliastur indus \\
15. Pariah Kite & 15. Milvus migrans \\
16. Bittern & 16. Botaurus stellaris \\
17. Grey Heron & 17. Ardea cinerea \\
18. Wire Tailed Swallow & 18. Hirundo smithii \\
\hline
\end{tabular}

\section{DISCUSSION}

This vast expanse of freshwater ecosystem in addition to its aesthetic beauty and recreational value is a potential habitat for various forms of invertebrates and vertebrates but the main threats to the system include the direct or indirect influence of various types of human activities. Domestic sewage, Industrial wastes, detergents etc. that are indiscriminately dumped into the lake results in eutrophication, Oxygen depletion and consequent reduction in aquatic life especially fishes. The organic wastes dumped into the system also accelerate the multiplication of floating weeds affecting light penetration into the deep water. Faecal contamination of water by the slum dwellers in the bank of the lake in addition to making the whole place stinky enhances the multiplication of Coliform bacteria.

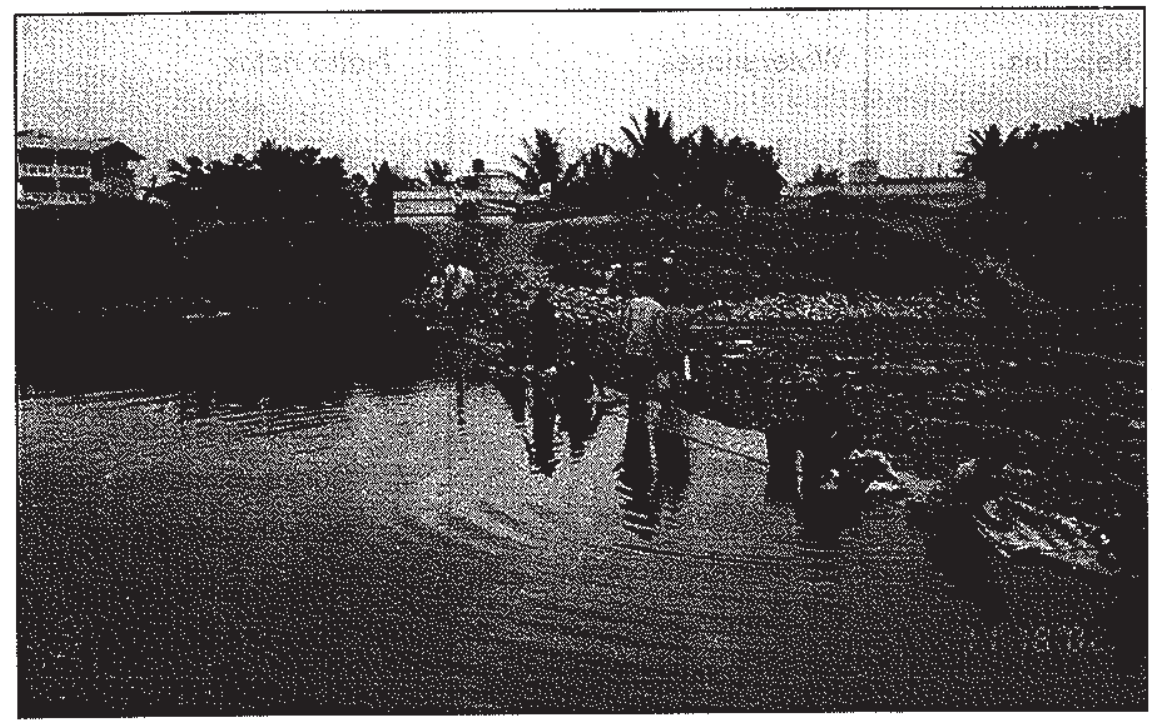




\section{CONCLUSIONS}

Immediate restoration strategies include:

1. Cleaning the water of all floating weeds, which prevents light penetration. At present this is carried out in phases since Eichornia multiplies very tast its removal has to be done at a single stretch. Othenwise it will result only in huge loss of money.

2. Washer men in the bank of the lake should be rehabilitated and provided alternate source of water.

3. Management strategies should focus on bank vegetation that supplies cover and food to birds, amphibians etc. A natural buffer of vegetation should be developed along the wetland margins.

4. The slum dwellers along the banks of the lake should be rehabilitated or provided proper toilet facilities.

5. As an effective measure for further diversity, crocodiles along with detritivorous fishes, turtles etc could be introduced in the lake.

\section{REFERENCES}

1. Dagg, A.l(1970). Wild life in urban areas

2. Davis, A.M and T.F. Glick(1978). Urban ecosystem and island biogeography.

3. Davey, S.P(1976). The role of wild life in an urban environment.

4. Geis, A.D(1980). Elements of an urban wild life program.

5. Hoover, R.L(1976). Incorporating fish and wild life values in land use planning.

6. Scientific stream pollution analysis - Nemerow 